Otakar A. Funda. K filosofii náboženství. Praha: Nakladatelství Karolinum 2017, $103 \mathrm{~s}$.

\title{
Jiří Gabriel
}

Záložka knihy představuje autora jako religionistu (vzdělaného na studiích protestantské teologie v Praze a Basileji) ${ }^{1}$ a filosofa (absolventa FF UK) zaměřeného na „filosofii náboženství, tj. na filosofickou reflexi náboženské víry. Podněty ke svým religionisticko-filosofickým úvahám několik let čerpal i jako pastor protestantské církve. Pro svou habilitační práci z teologie Myšleni o viŕre a myšlení viry zvolil téma „nenáboženská interpretace křestanské víry“, ${ }^{2}$ k její obhajobě byl však připuštěn až v roce 1990, kdy začal přednášet filosofii a religionistiku na $\mathrm{Hu}$ sitské teologické fakultě UK. Po čtyřech letech přešel na Pedagogickou fakultu UK, na níž pak působil po svém jmenování v roce 2003 jako profesor. Ve svých spisech $^{3}$ se zabýval problémy spjatými

$1 \quad$ Postgraduální studia na ThF a FF v Basileji Funda uzavřel v r. 1971 dizertací T. G. Masaryk, sein philosophisches, religiöses und politisches Denken, již pak v r. 1978 v zahraničí vydal jako svou první knižní publikaci.

2 V nenáboženské interpretaci křestanské víry Funda spatřuje možnost jak doložit, že mnohé dosavadní výklady o vzniku a působení náboženství znamenaly jeho „jednostranné zúžení a tím byly vzhledem k tématu neadekvátní" (s. 10).

3 Víra bez náboženství (1994), Znavená Evropa umírá (2002), Mezi vírou a racionalitou (2003), Když se rákos chvěje nad hladinou (2009), Racionalita versus transcendence. Spor Hanse Alberta s modernimi teology (2013). Seznam Fundových publikací sborníkových a časopiseckých obsahuje s osobním směřováním od vyznavačství víry v duchu českobratrské církve evangelické $\mathrm{k}$ zájmu o vědeckou religionistiku a filosofii náboženství jako disciplínám kompatibilním s jeho příklonem $\mathrm{k}$ racionalistické a humanistické filosofii. V knize k tomu dodává (s. 31): „Sám jsem prošel cestou od náboženské filosofie (typu demytologizace a existenciální interpretce křestanské víry) k filosofii náboženství, koncipované z pozice logického pozitivismu korigovaného kritickým racionalismem."

V kapitole Člověk tvor náboženský se Funda v podstatě zabývá výrazy odvozenými od „náboženství“: substantivní „náboženskostí“ a adjektivním „náboženský (-á, -é)“: tedy termíny - člověkem za jistých okolností osvojenými, někdy považovanými za apriorní - pro interní vztah člověka k náboženství, promítající se v jeho tendencích vykládat si, a třeba i řešit, některé osobní i společenské otázky (zejména tzv. světonázorové: ontologické, noetické, etické aj.) s ohledem na věrouku daného náboženství a na její aplikace na oblast našeho světa a bytí. Funda ovšem vznik a trvání náboženství (a tedy i náboženskosti) vysvětluje odkazy na dobové podmínky života lidí, na jejich historicky omezené možnosti dospívat při řešení všech problémů $\mathrm{k}$ adekvátnímu oznání skutečnosti,

např. jeho heslo $\mathrm{v}$ internetové podobě Slovniku českých filosofü. 
povahy a př́činné souvislosti ,jevư“, s nimiž se setkávali. Čtenář by se proto neměl některými Fundovými formulacemi v této kapitole nechat svést $\mathrm{k}$ názoru, že by se jeho proklamovaný ateismus mohl vykládat pouze jako nějaký „kvaziateismus“. Např. že by Fundovo prohlášení „Bůh není vyřízené téma“ nebo výrok „především platí, že Bůh je šifrou nejhlubší dimenze lidství“ četl jako ontologickou tezi vztahující se k božímu bytí. Fundovy komentáře a poznámky s takovými slovními spojeními čtenáŕ shledá na více místech knihy - a přesvědčí se, že by se $s$ jejich vlastními hodnoceními neměl ukvapovat. Pasáž o závažném vztahu etiky a náboženství Funda doprovodil několika citáty nesporných autorit o přednostech náboženské etiky, o odvěkém spojení náboženství a etiky a důvodech, které toto spojení upevňují (s. 15).

Ve svém výkladu o původu náboženství Funda vychází z premisy, že náboženství je lidský jev, a krátce se zmiňuje o tom, co člověka $\mathrm{k}$ tomuto „kulturnímu dílu“ motivovalo. Nejstručněji tu rozhodující výzvu Funda shledává v prostém faktu, který připomíná slovním spojením opakovaným v záhlaví sudých stránek knihy: Člověk bytost se vztahujicí. Rodí se a žije v jistém vnějším prostředí, s nímž se musí nějak vyrovnávat, aby se udržel při životě. To sice platí pro všechny živé tvory, ale - jak se ukázalo - jen lidské bytosti byly dostatečně „predestinovány“ $\mathrm{k}$ tomu, aby do vztahů ke svému okolí, do své noetické činnosti, zapojovaly spolu se svými smysly a pohyblivostí i mozek, schopný rozvíjet své předpoklady i k racionální noezi, k myšlení a jemu odpovídající mluvě. Na rozdíl od teologů a antropologů Funda neuvažu- je hned o tom, zda schopnost pravěkého člověka, směřujícího k celistvějšímu pohledu na svět, nesvědčí o tom, že mu byla do vínku dána také nadpřirozená duše, jíž by se dala vyložit jeho schopnost „duševních “ výkonů. Spokojuje se domněnkou, že „, člověku bylo od počátku něco kladného, pozitivního, tvưrčího, ale i něco dábelského, stvořil zlo“. „Stvoření zla“ má ve Fundově výkladu vzniku náboženství důležité místo, byt ne v tom rozsahu a dosahu jako v myšlení náboženském. Zlo „přestalo být jen jevem, ale stalo se metafyzickou veličinou. Prostupuje celými lidskými dějinami jako lidská konstanta“. Vycházeje z tohoto poznání nabízí svou odpověd' na otázku původu náboženství (s. 9). „Osobně se domnívám, že v hlubinách vzniku náboženství je přítomno lidské volání po záchraně, po vykoupení, vysvobození z moci zla."

$\mathrm{S}$ touto hezkou větou o nehezkém jevu (zlu) zřejmě budou souhlasit i současní věřící. Nepředpokládá však tento výrok o „hlubině“ vzniku náboženství, že „volající" má nějaké ponětí o adresátovi svého volání, který je může nejen zaslechnout, ale mít i vrili a možnost volajícímu vyhovět? Koncept člověka volajícího po záchraně a vykoupení otevírá Fundovi přístup k člověku - což je pro religionistu velmi významné - reflektujícímu, že jeho „pobývání na světě se rozprostírá mezi úzkostí a nadějí": Funda mu tedy může připsat i otázky, o nichž soudí, že se „prokáží jako stále se vracející a otevřené“ (s. 10). Jejich ráz je převážně etický, i když s jistými předpoklady zejména ontologickými. ${ }^{4}$ Souborná otázka Odkud, $k$ čemu

4 Fundovi slouží i jako argumenty pro tvrzení, že náboženství není založeno jen 
a kam směřuji? implikuje ještě další, např. Na čem skutečně záležri? Co je dobré? Co je správné? Co mám dělat? Proč neni všechno jedno? Pro další směřování náboženského myšlení je významné (a také výhodné), že se jejich subjekt takovým tázáním zaměřuje na vlastní nitro, na svůj osobni vztah k „božskému/Bohu“.

Slovním spojením „člověk tvor náboženský“ může Funda u čtenáře vyvolávat dojem, že považuje člověka za tvora jakoby a priori vnitřně vybaveného $\mathrm{k}$ vytváření náboženských představ a $\mathrm{k}$ jejich spojování do víceméně uceleného názoru - náboženství. Tak by se mohla chápat i jeho formulace, že „dimenze vztahování, jako nedílný průvodič lidství, zakládá náboženství jako veskrze lidský fenomén" (s. 11). Domnívám se však, že má Fundovi pouze pomoci vyjádřit myšlenku, že nejen filosofie, ale i náboženství (se svým učením i praxí) vznikaly a vyvíjely se „přrirozeně“, v procesu lidského poznávání, a že se tudíž na zrodu náboženství nepodíleli žádní nadpřirození činitelé. Tím také $\mathrm{k}$ etice jako filosofické disciplíně přistupuje jako $\mathrm{k}$ veskrze lidskému fenoménu. Že jsou její zmíněné otázky předmětem zájmu učení-teorie náboženské i filosofické, Funda sděluje konstatováním jejich „společného pomezí. Skutečnost, že lidé mívají tendenci vykládat si své setkání s „etickým nárokem“ jako „setkání s transcendencí, s nepodmíněnou a bezpodmínečnou výzvou“, tedy vlastně jako setkání s Bohem (nebo alespoň s „božským“), vede Fundu k názoru,

na zvulgarizované představě, že člověk si bohy vymyslel ze strachu před přírodními jevy, jež si neuměl vysvětlit. že pro religionistu i filosofa náboženství může mít při výkladu vzniku a vývoje náboženství koncept „existence nepodmíněného nároku“ závažnější význam než sama představa božstva či Boha (s. 17).

Funda se zamýšlí i nad vývojem ateismu jako legitimní filosofické pozice v evropské kultuře od doby osvícenství až po současnost. Ale i v sekularizované části Evropy Funda nachází trvající formy dosavadní religiozity, renesanci postmoderní religiozity a „kvazináboženství“. Zmínil jsem se už o tom, že Funda se někdy vyjadřuje tak, že by jeho proklamovaný ateismus mohl být pochopen jako kvaziateismus. Že citovaná teze „Bůh není vyřízené téma" by se dala vyložit i v tom smyslu, že idea Boha se stále uplatňuje v životě jednotlivců i ve společnosti (byt pozitivně i negativně). O pojmu/slovu „Bůh“ Funda říká, že jde o šifru pro „nejhlubší dimenze lidství. Existenci slov (i pojmů) nám dosvědčují odpovídající slovníky; co však v reálném světě dosvědčuje existence šifer a jakými jejími interpretacemi se čtenář osvobodí od svých pochybností, zda tomu šifrovanému dobře rozumí? I na takového čtenáře autor knihy pamatoval při jejím psaní, a to nejen jednotlivými komentáři a poznámkami ke svým ústředním tezím, ale i celými kapitolami. ${ }^{5}$

5 Původ náboženství, Člověk tvor náboženský, Náboženství tématem filosofie, Vztah filosofie a náboženství, Pohled zevnitř a úsilí o nepředpojatost a nezaujatost - rozdíl mezi teologií a religionistikou, Řeč náboženství, Náboženství a věda, Náboženství jako hermeneutické drama zpřítomnění, Filosofická reflexe mýtu o Kristu, Spor o Boha v rámci křestanského diskursu, Biologický humanismus, kritický realismus a kritický racionalismus, 
Pojednání o vzniku náboženství naznačilo, že v pokročilejších náboženských úvahách má ústřední roli koncept Boha, představovaného v oficiálních vyznáních křestanského náboženství jako „otce všemohoucího, stvořitele nebe i země, všeho viditelného i neviditelného“. Proto dávám přednost kapitole Spor o Boha v rámci křstanského diskursu (s. 59-76). Funda byl recenzenty knihy pochválen za její jazyk i za dobrou srozumitelnost výkladi̊, to však neznamená, že bychom neměli dávat pozor, zda všemu v nich rozumíme. Sám autor nás $\mathrm{k}$ tomu nepřímo nabádá, když např. v souvislosti s tříděním náboženství podle jejich „smyslu“6 píše o náboženství, či spíše nábožnosti v existenciálně etickém smyslu (s. 22): „V této rovině není bůh chápán substančně, ale existenciálně, jako událost, jako bůh, či vlastně již Bůh, který se stává výzvou a nárokem, jako Bůh, kterého člověk zakouší jako existenciální, v podstatě nepředmětnou dimenzi menzi etické transcendence, jako setkání s nepodmíněným.“

Rovněž touto kapitolou (nejdelší v knize) Funda zůstal s tématem „spor o Boha“ v křestanské rovině. Ve sporu se Fundovi vyjevuje vývoj novodobého křestanského teologického myšlení, jenž měl také roz-

Racionalita jako způsob myšlení, jednání, žití i umírání, Facit, Údajná budoucnost náboženství jako toku interpretací.

6 Funda rozlišuje 1) náboženství v panteistickém smyslu, 2) náboženství v supranaturalistickém smyslu, 3) náboženství v metafyzickém smyslu a 4) náboženství v existenciálně etickém smyslu. Ke 4) přidává, že „víra jako existenciální poloha života se diferencuje od náboženství jako světonázorového konceptu“" (s. 22). hodující vliv i na Fundovu radikální změnu názoru na náboženství vůbec. Ukazuje se v něm rozdíl, jak k ústřednímu úkolu teologie - řeči o Bohu, jeho bytí a působení, přistupují ontologizující teologové a náboženští filosofové na jedné straně a filosofové, zejména stoupenci kritického racionalismu a realismu na straně druhé, kteří (jako Funda) své filosofické i nenáboženské stanovisko považují za výraz svého poznání a pochopení reálného světa, lidského místa v něm a také vlastního sebepochopení. Zkrátka: Funda se svými poměrně dlouhými a myšlenkově náročnými cestami dospěl k přesvědčení, že ontologické koncepce, které nelze verifikovat a falzifikovat, nelze vydávat za skutečné (vědecké) teorie o jsoucnu (s. 62). Za takovou „teorii“ pak považuje i teologickou a nábožensko-filosofickou nauku o b/Bohu a nadpřirozeném světě vůbec. Neštěstím většiny náboženství podle Fundy je, že nechtějí zůstat mýtem a básní, nýbrž si nárokují pozici konzistentní světonázorové koncepce, relevantní ontologické teorie.

Protestantská teologie neuvažuje o Bohu jako ontologickém konceptu, a tak nepotřebuje svou víru v boží existenci podepírat přírodovědnými poznatky (s. 63): „Přešla do roviny vyznání, zvěsti, do roviny řeči symbolů, které nikdo není povinen dokazovat, ale které také nikdo necítí důvod falzifikovat."

Tady se nabízí místo ke sdělení, o jaké důvody Funda opírá své mínění o neexistenci Boha. V knize (na s. 74-76) uvádí tři osobni dưvody, odkazující na dějiny: 1) Dějiny se svou ambivalencí, plné hrůz a nesmyslného utrpení, nijak nenasvědčují, že by měly milostivého a laskavého 
Pána (i když někteří soudí, že ten Pán vyčkává, aby jednou měl slovo poslední). 2) Naše lidské dějiny, s dějinami náboženství samého, vedou spíše k závěru, že se nad nimi neklenou žádné svaté dějiny, z nichž by přicházelo zjevení, že náboženství nejsou pouze fenoménem lidských dějin a kultury. 3) Dějiny ukazují na dobovou podmíněnost všech svých jevů, včetně pozitivních náboženských výpovědí, jimiž jsou náboženství a jejich historie tradovány. - Nejen přesto, ale právě proto Funda v této kapitole také sděluje, že náboženské ideje, domněnky, představy, naděje (i tzv. prostých řadových věřících) jsou pro religionisty i filosofy náboženství cennými informacemi nejen o stavu a proměnách náboženské víry, ale také o věřících samých, o tom, proč a jak ke své víre a k jejím formulacím dospívají, co znamenají pro jejich osobní i společenský život.

Souhlasím s autorem knihy, že ukazuje, a zároveň odsuzuje (!), jak se někdy v novodobých teologických i nábožensko-filosofických textech problémy s „existencí Boha“ překrývají různými slovními spojeními, jakoby ekvivalentními možnostmi pro jeho pojmenování a bližší představení. Ke svému názoru, že pro ateistického filosofa náboženství je spor věřících o Boha bezpředmětný, Funda dodává, že filosof by neměl na „otázku o Bohu“, pokud je prezentována v souřadnicích tvrzení, rezignovat, a tak ji ponechat v nerozhodnuté či údajně nerozhodnutelné neutralitě, protože by tím přenechal prostor teologii a náboženské filosofii, které, aniž by cokoli dokladovaly, předkládají veřejnosti tvrzení, že Bůh existuje, jako pravdivé tvrzení ontologické, jako základní tvrzení náboženského světového názoru (srov. s. 69).
Funda uvádí, že nikdy „nevedl polemiku s polemikou, která představovala určité mínění, jež nebylo možné verifikovatelně argumentovat“, protože a) nedoložené mínění je třeba respektovat, i když je nesdílíme, ale b) nedoložené tvrzení je třeba přejít jako bezpředmětné (s. 76). Za povšimnutí ovšem stojí, že na tyto své noetické zásady sám reaguje otázkou „na čem pak založíš etiku?"“. Svými citovanými zásadami totiž myšlení i řeč o našem prožívání světa a tím i stanovení určitých mravních hledisek a norem vykázal do světa mínění, se kterými sice lze vést dialog jako o odlišných míněních, ale nikoli spor jako v případě tvrzení, a že právě tím si dal podnět k otázce, jestli „nezůstává pak i etika, její východiska, hodnoty, založení vydána napospas subjektivismu a relativismu?".

Funda svou filosofickou koncepci formuluje jako biologický humanismus a kritický racionalismus. Jako „hluboce přesvědčený realista“ považuje za nepochybnou nejen objektivitu světa, ale i názor, že příroda člověka jako svou nedílnou součást uspořádala tak, že nás naše smysly informacemi o světě mimo nás neklamou. Je proto také stoupenec korespondenční teorie pravdy jako shody se skutečností, kterou chápe jako komplexitu komplementarit komponent $v$ korelaci, kontinuitě a kontextu, dodávaje $\mathrm{k}$ tomu, že tuto relativnost nezaměňuje za relativismus. To jsou úvodní věty předznamenávající Fundovo filosofické směřování $\mathrm{k}$ odpovědi na otázku, kterou si sám položil, na filosofické založení svého etického stanoviska. Stránky, které tomuto úkolu věnoval, řadím mezi nejlepší v této knize, a proto - paradoxně - z jejich obsahu tu uvedu jen to 
nejpodstatnější, protože předpokládám, že si je čtenáŕ, jehož Funda zajímá jako religionista a filosof, sám pozorně přečte.

Funda vychází z toho, že objektivní skutečnost má svou svébytnou realitu, nezávislou na naší interpretaci. Z toho odvozuje, že hodnotou není to, co za hodnotu považujeme, nýbrž již to, co samo v sobě je hodnotou. Tedy sama skutečnost na nás nezávislého vnějšího světa, světa přírody včetně světa lidí a lidských vztahů. Jako Nikolai Hartmann tedy nezakládá etiku na mravním vědomí v nás, nýbrž na úctě před jsoucím, které jsme nevytvořili, a které proto musíme chránit před zničením. Nejvyšší formou jsoucího je život. Funda tedy, s přímým odkazem k dílu Alberta Schweitzera, zakládá etiku na „úctě k životu, na životě jako hodnotě nejvyšší a nesporné“, nezávislé na našich míněních a etických koncepcích (s. 79); tuto integrující etickou pozici nazývá biologickým humanismem a staví jej výše než humanismus křestanský. $\mathrm{V}$ případech, kdy zájem na ochranu a uchování vlastního života se staví proti zájmu druhého na ochranu jeho života, je třeba volit postoj rozumnosti; nastupuje dimenze rozhodnutí, sebepřesahování, dimenze člověka jako bytosti se vztahující, mravně odpovědné, která se rozhoduje, co je účelné, dobré a co je třeba učinit. Otázku náboženské filosofie, zda může člověk překročit svůj egoismus sám ze své racionality, ze sekulárního humanismu, a žít odpovědný a kvalitní život bez náboženství, bez metafyziky, bez transcendence, považuje za bezpředmětnou. Jde pouze o pokus vehnat člověka do slepé uličky, který má doložit, že bez Boha to nejde (s. 82): „Ano, člověk sám nestačí, selhává a prohrává. Racionalita, která mu zbývá, má své hranice. Ale nic lepšího nemáme."

V kapitole Náboženství jako hermeneutické drama zpř́tomněni (s. 42-53) se Funda zabývá společnou komponentou různých náboženství, potřebou sdělení. Zájmem každého náboženství je, aby jeho obsahy, ritus i nauka byly sdíleny a sdělovány. Rozumí se, že "zájmem náboženství" se tu míní zájem lidí majících $\mathrm{k}$ danému náboženství nějaký vztah, jako jeho představitelé, tvůrci, vyznavači, členové náboženské společnosti (církve), jež se k němu hlásí jako ke svému vyznání. Funda si všímá různých způsobů těchto sdělení a připojuje vysvětlující komentáře $\mathrm{k}$ jejich formě i obsahu. Tak se „náboženství stává prostorem, v němž dochází $\mathrm{k}$ hermeneutickému dění. Jeho potřebu vyvolává nejen povaha objektů náboženského myšlení, ale i to, že „mladší tübingenská škola uvedla do protestantské teologie vědomí dějinnosti a dobové podmíněnosti každé výpovědi“ (s. 42). V tom Funda nachází také důvod, proč se většina náboženství (jejich teologové a historici) snaží „přivést $\mathrm{k}$ řeči a $\mathrm{k}$ porozumění to dříve řečené“. Vychází se z „určitých sdělení, mimořádných sdělení, ze zjevení a jeho či jejich zachycení ve svatých textech kdysi“ (s. 43). Časová propast mezi „tehdy“ a „nyní“ má být překlenuta na bázi prožitku, prožitku zpřítomnění a zpřítomňujícího prožitku zároveň (s. 43). Funda rozlišuje sedm způsobů-forem, které v křestanském náboženství představují (předvádějí) př́ípady hermeneutického dramatu zpřítomnění. Jejich názvy ukazují sedm cest k uvažovanému zpřítomnění obsahu a smyslu někdejších sdělení, i oblasti, k nimž se vztahují (s. 44-53). 
Jak se může zpřítomňovat starší náboženský text, se Funda pokusil ukázat v kapitole Filosofická reflexe mýtu o Kristu (s. 53-59). Připomněl, že mýtus o Kristu, na němž je založena křestanská víra, je v diskrepanci s postavou historického Ježíše. Ježíš nebyl tradován jako hlasatel humanity, ale byl mytizován jako Kristus, jako ten, skrze něhož Bůh odpouští hříchy a odpuštěním proměňuje lidský život. Mýtus o Kristu je mýtem „vykupitelským, spasitelským“, vycházejícím z lidské úzkosti, z pocitu marnosti a ztracenosti, z vědomí konečnosti a vlastních vin. Funda poukazuje mimo jiné i na to, „jak mnozí, kteří se v dějinách dovolávali mýtu o Kristu a kteří jej tradovali, se mu veskrze vzdalovali a dopouštěli se na Kristu zrady“; odvažuje se dokonce napsat, že „dějiny křestanské církve jsou především dějinami zrady na Kristu“ (s. 57). Síla tohoto mýtu však spočívá v tom, že i přes dějinné „zpronevěry církve“ osvědčil svou vnitřní podmanivou moc, proměnil lidské životy směrem k lásce, dal jim integritu a osvobodivou naději.

Funda na základě Popperovy kritiky historicismu a mesianismu vyslovuje vážné pochybnosti vưči mýtu o Kristu, odmítá myšlenku vykoupení a doporučuje racionálně kritické řešení všech problémů, které přináší život. Z pozice kritického racionalismu však nemůže a nechce ignorovat fakt, „že racionalita není celá pravda o člověku a lidském životě. Byli bychom nepřiměření vůči skutečnosti, tedy nevědečtí, kdybychom ignorovali, že každý člověk prožívá v životě chvíle, kdy mu nestačí racionalita, kdy potřebuje lásku, kdy potřebuje milost, kdy potřebuje odpuštění...“ (s. 59). Uzavírá tedy tuto kapitolu konstatováním, že mýtus o Kristu má větší sílu než racionalita, nebot odkazuje k naději.

Podle mého soudu nejcennější na Fundově Filosofii náboženstvi je to, že její autor i jako ateista považuje náboženství za jeden z klíčových jevů lidských dějin a kultury a že v ní toto své přesvědčení rovněž přesvědčivě dokládá. Dosáhl toho tím, že svou knihu pojal jako pozvání čtenářů k uvedení do problematiky „filosofické reflexe náboženství“, že tedy k jejímu napsání přistoupil jako religionista a zároveň jako filosof náboženství. Napsal ji nejen pro studenty, ale pro všechny čtenáře, kteří jsou ochotni s autorem uvažovat o náboženství bez vázanosti $\mathrm{k}$ určitému náboženskému vyznání, jeho sdílení či praktikování; adresoval ji zájemcům, kteří nejsou profesně filosofy, religionisty nebo teology. O obecnou sdělnost svého textu se snaží rovněž proto, že filosofie, jak jí rozumí, má vedle poznávacího také (někdy především) vzdělávací a výchovné poslání. Filosofii náboženství bere jako filosofickou disciplínu, jejímž úkolem je reflektovat náboženství, prostě řečeno: podat zprávu o tom, co filosofie soudí o náboženství jako další (vedle filosofie) svébytné a často také konkurenčně pojaté snahy po vytvoření uceleného světového a životního názoru, vybudovaného na základních premisách náboženského (teologického, církevního) učení. Filosofie náboženství tedy také zkoumá vlivy filosofie na vytváření náboženské filosofie. 
doc. PhDr. Jiří Gabriel, CSc.

Brno, Česká republika

jgab@post.cz 